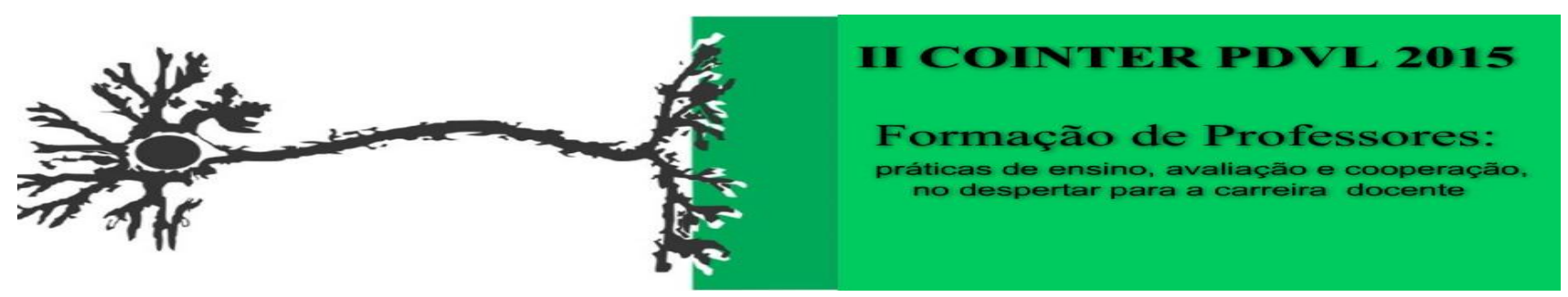

\title{
A RELAÇÃO INTERPESSOAL E A PRÁTICA DOCENTE CONSTRUINDO UM NOVO CAMINHO PARA O ENSINO-APRENDIZAGEM
}

\author{
Apresentação: Relato de Experiência \\ Mádson Francisco da Silva ${ }^{1}$; Natália Maria da Silva ${ }^{2}$;Paulo Sérgio Dantas da Silva ${ }^{3}$; Ana \\ Maria Sotero Pereira ${ }^{4}$
}

\section{Introdução}

A educação apesar de ser entendida por Freire como real possibilidade de mudança para a sociedade, é um desafio para professores, alunos, família e para os outros sujeitos envolvidos nesse caminho de ensino e aprendizagem. Desse modo, esse texto irá relatar a experiência de um estudante de pedagogia em uma observação na sala de aula de uma escola municipal, onde estava realizando uma pesquisa e que simultaneamente teve uma visão diferente da sala de aula que infelizmente na contemporaneidade vem sendo caracterizada como um espaço de desordem e não como um lugar de ensino e aprendizagem.

\section{Relato de Experiência}

Esse relato trata de um determinado estudante do quarto período de pedagogia, que realizou uma pesquisa para compreender o currículo educacional, o planejamento e as didáticas utilizadas na educação básica, especificamente no fundamental I. Onde, nesse período preparatório que sinalizava a ida ao lócus da pesquisa, o estudante elencava em si e partilhava com seus colegas a sua visão sobre a escola e o que esperava quando chegasse nela, esperando encontrar na sala de aula da pesquisa uma professora desanimada com a educação, estudantes sem saber ler e com dificuldades na escrita, estudantes com atitudes violentas, pais ausentes e desempenho escolar não construído. Nesse horizonte, ao chegar à escola e se direcionar a série escolhida, o universitário se deparou com uma sala organizada, com estudantes participativos que demonstravam domínio sobre a leitura e escrita, além, de uma visão critica e reflexiva sobre as coisas, registrou também a participação dos pais na vida escolar dos filhos e identificou a professora como articuladora de uma cena inacreditável. Ainda sem acreditar no que estava observando e vivenciando, o estudante aproveita sua pesquisa para questionar a professora sobre o que vê, já que suas concepções apareciam estar erradas naquele momento. E seguindo esse norte, foi possível perceber no discurso

\footnotetext{
${ }^{1}$ Pedagogia, Universidade de Pernambuco, mamadson123@hotmail.com

${ }^{2}$ Pedagogia, Universidade de Pernambuco, silva.n.mda@gmail.com

${ }^{3}$ Geografia, Universidade de Pernambuco, paulo_dantas@outlook.com

${ }^{4}$ Mestre em educação, Universidade de Pernambuco, asotero.upe@hotmail.com
} 
da professora que realmente aquela turma já foi à pior da escola, que os pais já foram os mais ausentes e que daqueles alunos vinham o pior rendimento da unidade escolar. Entretanto, sendo formada em geografia, com especializações na área da pedagogia e partindo da sua experiência, ela resolveu sair de trás da mesa e se colocar no lugar do aluno, no mundo dele e de sua família, promovendo atividades que fomentavam o relacionamento entre eles mesmo e com ela como professora, buscando também se relacionar com a família para fazer com que todos pudessem enxergar na educação uma possibilidade de mudança. E assim se fez. A professora conseguiu através de sua prática transformar a sua sala de aula, conseguindo ensinar e elencar aprendizagem através das relações dos alunos com os outros e com o mundo, porque como diz Campos (1987) a "aprendizagem é um processo que envolve a participação total e global do individuo, em seus aspectos físicos, intelectuais, emocional e social". Ou seja, para o ensino acontecer com eficiência rumo a aprendizagem, é necessário que o conhecimento possa ser cultivado nas coisas que estão em volta do aluno, para que assim, o saber possa ter para ele um significado mais real e a escola como espaço de ensino, seja mais interessante. Partindo dessa experiência que a observação da pesquisa proporcionou, o estudante teve um novo olhar sobre a escola apesar de seus desafios e começou a entender o que propõe Feldmann(2009), quanto a necessidade da formação atual e da escola contemporânea formar e ter professores que consigam se relacionar não só com os saberes, mas também com as pessoas, que naturalmente elenca aprendizagem.

\section{Considerações}

Diante do relato apresentado, pode-se concluir que é importante priorizar o relacionamento entre as pessoas, pois, infelizmente temos nos esquecido de partilhar da vida para que outros também possam crescer e aprender a partir das nossas e de outras experiências. Desse modo, sugere-se que a formação e a prática docente na atualidade possam formar professores que estejam hábitos a incentivar a aprendizagem a partir da vida, instituindo também um ensino que esteja ligado a vida pessoal e social do sujeito. Para que assim, a prática docente e a aprendizagem tenham um significado maior.

\section{Referências}

CAMPOS, Dinah Martins de Souza. Pisicologia da Aprendizagem, A aprendizagem: conceito e características. Petrópolis, Vozes, 1987.

FELDMANN, Marina Graziela. Formação de Professores e Escola na Contemporaneidade. Editora Senac São Paulo, 2009.

FREIRE, Paulo. Pedagogia da autonomia: saberes necessários à prática educativa. 9. ed. São Paulo: Paz e Terra, 1996. 165 p. 